\title{
Der Anthropos im Anthropozän
}

Die Wiederkehr des Menschen im Moment seiner vermeintlich endgültigen Verabschiedung

Herausgegeben von Hannes Bajohr 
ISBN 978-3-11-066525-3

e-ISBN (PDF) 978-3-11-066855-1

e-ISBN (EPUB) 978-3-11-066547-5

Library of Congress Control Number: 2020930903

Bibliografische Information der Deutschen Nationalbibliothek

Die Deutsche Nationalbibliothek verzeichnet diese Publikation in der Deutschen Nationalbibliografie; detaillierte bibliografische Angaben sind im Internet über http://dnb.dnb.de abrufbar.

(c) 2020 Walter de Gruyter GmbH, Berlin/Boston

Druck und Bindung: $\mathrm{CPI}$ books $\mathrm{GmbH}$, Leck

Coverabbildung: Niels Kalk: Flow (2015)

www.degruyter.com 